and long term care aid, thus saving our health system dollars. Lindsay Kuhn dared us to think about moving beyond the traditional supervising physician-PA relationship to embrace PAs as first-line research colleagues. The audience applause response meter indicated that each of these daring ideas was well received We all agreed that encouraging out-of-the-box thinking made for a stimulating conference.

The enthusiasm and engagement at the 2015 PBRN Conference was high from start to finish and people are excited about coming back next year. The 2016 PBRN Conference will be July 11-12, 2016 in Bethesda, Maryland with the theme of "Dissemination and Implementation: Ensuring PBRN (and Patient-Centered Outcomes) Research Evidence is Understood and Used." See you next year!

LJ Fagnan, MD and Rowena Dolor, MD, MHS

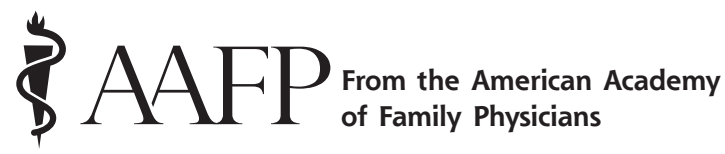

Ann Fam Med 2015;13:498-499. doi: 10.1370/afm.1857.

\section{DIRECT PRIMARY CARE (DPC) SUMMIT DRAWS HUNDREDS OF ENTHUSIASTIC FAMILY PHYSICIANS}

The numbers don't lie. The Midwest's first Direct Primary Care (DPC) Summit, held July 10-12, 2015 in Kansas City, Missouri, even surprised event organizers by racking up 317 attendees hailing from 45 states. Organizers knew they'd break even with 200 attendees, but 1 week ahead of the event, registration soared past 300 and suddenly, the 3 -day meeting was sold out.

When 10 people showed up to register on site, the AAFP and 2 event partners - the Family Medicine Education Consortium, Inc and the American College of Osteopathic Family Physicians_obliged and squeezed a few more chairs into 3 already packed hotel meeting rooms.

This new practice model-in which physicians charge patients a flat monthly or annual fee in exchange for a wide array of health care services-has piqued the interest of work-weary physicians who like the idea of taking back control of their practices and eliminating insurance hassles.

According to the AAFP's 2014 Practice Profile, 2\% of family physicians are already practicing in a DPC setting. Although the survey indicated very few family physicians were transitioning to a DPC setting as of December 2014, 28\% of family physicians are aware of DPC and are exploring the model in more depth before making a decision. Only 21\% have explored and decided against the DPC model, and $49 \%$ are unaware of DPC.

\section{Engaging the Audience}

Attendees at this third national DPC Summit were immersed in learning that came directly from experienced physicians eager to share their knowledge and bring their colleagues on board.

For instance, physicians heard about how to start a new DPC practice or transition an existing one, employ marketing techniques, understand legal issues, recognize financial pitfalls, and navigate a regulatory maze that varies from state to state.

They were even privy to a candid onstage discussion between DPC physician Ryan Neuhofel, MD, of Lawrence, Kansas, and one of his patients, 56-year-old Blaine Milther, who relayed, with humor and honesty, his experiences dealing with a deeply entrenched health care system that left him stranded after a stroke and a diagnosis of type 2 diabetes.

Milther, a self-described small business owner of meager means, said his local safety-net clinic dismissed him as too wealthy and handed him a flyer on his way out. That sheet of paper led him to Neuhofel's practice, NeuCare (http://neucare.net).

A year and a half later-after an intensive physician/patient partnership that time-strapped FPs in traditional practices only dream about-Milther is back to full-time work at his heating and cooling company. He's lost 50 pounds and has swapped twice-daily insulin injections for an oral medication.

Milther described Neuhofel as a "breath of fresh air."

Their 1-hour presentation had the audience alternately laughing and applauding. In fact, during the question-and-answer period, a physician approached the microphone and appealed to Milther to meet him later at the Massachusetts House to testify on behalf of the DPC model. "They need to hear from patients like you," said Jeffrey Gold, MD, of Marblehead, Massachusetts.

\section{Getting Down to Basics}

Two family physicians, both DPC practice owners, teamed up for a session that addressed how to start a DPC practice.

Kenneth Rictor, MD, owner of Scotland Family Medicine (http://scotlandfamilymedicine.com) in Scotland, Pennsylvania, has been in practice since 1988 and transitioned his traditional solo practice to the DPC model in 2014 . About $12 \%$ of his patients made the change with him, bringing his current patient panel to about 550 . 
"Each of our patients gets a half-hour visit, and I see 12 patients a day," Rictor told the audience. "I've received more thank-you notes my first year in direct primary care practice than in my entire career," he added.

Rictor ticked off some of the advantages of the new way of doing business. For instance, patients enjoy

- Limited wait times in the renamed "reception room"

- Improved access to care both from Rictor and ancillary service providers

- Increased office visit time

- Access to discounted services and complimentary procedures

The practice also dispenses medications at hugely discounted prices. For example, one patient's $\$ 40$ monthly prescription bill was reduced to just $\$ 3$ for a 3-month supply.

Rictor routinely tells patients, "If you're hesitant to take your medication because of the cost, I can help you with that." He told the audience that when he realized the markup on medication prices, he decided to forgo a profit and include medications as a regular part of his patients' care.

That's the beauty of this practice model.

"We're kings and queens of our castle," said Rictor. "We can design our practices any way we want to."

For co-presenter Joseph Sheppard, DO, the story began very differently but has had the same happy ending. In 2014, he'd just completed his residency training and jumped straight into setting up his solo DPC practice, Free Market Physician (http://www.freemarketphysician.com) in Neosho, Missouri.

"For me, it was all about the freedom to be the doctor I wanted to be," said Sheppard. In other words, no more regulatory burdens posed by Medicare and other insurers, no more excessive documentation and coding, and no more hospital system bureaucracy.

About 100 patients joined the new practice during the first 2 months. Today, Sheppard's patient panel stands at 300 and is growing at a pace of about 25 patients a month.

His key message to the audience was this: Engage in good upfront financial planning. "The road to DPC is littered with the carcasses of physicians who didn't succeed," said Sheppard. "It is all about the moneybecause when you run out of money, you're out of business."

Sheppard flashed cash flow sheets on the screen behind him and discussed in detail how to increase revenues, decrease expenses, and deal with a net income that may initially be less than stellar.
He drew chuckles from the audience when he honestly assessed his current situation. At the 1-year mark, "My quality of life stinks," Sheppard conceded. He supplements his income with hours at a local emergency department and hospital calls. Moonlighting was a deliberate decision to avoid taking on additional loan debt.

"I'm working as hard as I did in residency, but it's worth 14 months of suffering to have the kind of life I want," Sheppard said. If all goes according to plan, those extra jobs will be a thing of the past come October or November.

"Blood and sweat is an investment, and it's worth something," said Sheppard.

\section{Looking for Change}

Attendees' stories varied as widely as those of the speakers. Take Jimmie Bailey, MD, of Crestview, Florida, who recently retired from the US Air Force and came to the summit looking for a practice option with a "reasonable level of activity."

"I don't have to work, I want to work. But I don't want to be overwhelmed," said Bailey. He'd like to stay involved in medicine and help uninsured patients get care, but in a fashion that harkens back to the days when medical care was between the physician and his patient.

"With the DPC model, we've come full circle," said Bailey.

Fresh out of residency, Mark Turshen, MD, of North Kingstown, Rhode Island, arrived at the summit just 1 week after joining a DPC practice started 1 year ago by a residency colleague. During residency, Turshen said he toiled for many long hours in a large, busy medical clinic that by necessity limited his time with patients. He described the real reward of DPC as the ability to forge "enhanced doctor/patient relationships."

When AAFP News approached Jill Mahoney, MD, of Scarborough, Maine, to ask why she came to the summit, she simply responded, "I couldn't do what I was doing anymore. I quit my job."

After 10 years of doctoring, most recently in a large physician-owned multispecialty practice, Mahoney said she was taking some time off to spend with her kids and create a business plan for her future DPC practice.

"I'm done spending all my time on paperwork and not with patients," said Mahoney. "I'm excited about being a doctor again."

Sheri Porter

AAFP News Department 